\title{
KAJIAN PENGARUH MODEL PROJECT BASED LEARNING TERHADAP KETERAMPILAN BERPIKIR KREATIF PESERTA DIDIK PADA PEMBELAJARAN FISIKA
}

\author{
Siti Maysyaroh ${ }^{1)}$, Dwikoranto1) \\ 1)Program Studi Pendidikan Fisika, Fakultas Matematika dan Ilmu Pengetahuan Alam, Universitas Negeri Surabaya, \\ Surabaya, Jawa Timur, Indonesia \\ Corresponding author : Siti Maysyaroh \\ E-mail : siti.17030184101@mhs.unesa.ac.id
}

Diterima 02 April 2021, Direvisi 14 April 2021, Disetujui 15 April 2021

\begin{abstract}
ABSTRAK
Penelitian ini bertujuan untuk mendeskripsikan pengaruh model Project Based Learning terhadap keterampilan berpikir kreatif peserta didik pada pembelajaran fisika. Penelitian ini menggunakan jenis penelitian library research dengan mengumpulkan data pustaka yang relevan dari berbagai sumber informasi. Teknik analisis data yang digunakan berupa kualitatif deskriptif yaitu menguraikan data, menganalisis dan membahas data, serta mengkaji kesimpulan dari data yang diperoleh. Sumber data yang dipilih berupa data sekunder yang diperoleh dari berbagai sumber jurnal ilmiah nasional, internaisonal dan prosiding. Berdasarkan hasil analisis dari penelitian terdahulu menunjukkan bahwa model Project Based Learning dapat meningkatkan keterampilan berpikir kreatif peserta didik pada pembelajaran fisika.
\end{abstract}

Kata kunci: library research; project based learning; keterampilan berpikir kreatif.

\begin{abstract}
This study aims to describe the effect of the Project Based Learning model on creative thinking skills of students in learning physics. This research uses the type of library research with the collecting relevant library data from various sources of information. The data analysis technique used is in the form of descriptive qualitative with deciphering the data, analyzing and discussing the data, and reviewing the conclusions from the data obtained. The selected data source is secondary data obtained from various sources of national, international and proceeding scientific journals. Based on the results of the analysis from previous research, it shows that the Project Based Learning model can improve students' creative thinking skills in physics learning.
\end{abstract}

Keywords: library research; project based learning; creative thinking skills

\section{PENDAHULUAN}

Pada abad 21, IImu Pengetahuan dan

Teknologi berkembang dengan pesat sehingga Sumber Daya Manusia harus mampu beradaptasi (Arnyana, 2019). Dalam meningkatkan kualitas Sumber Daya Manusia diperlukan sarana dan prasarana yang cukup mewadahi, salah satunya yaitu pendidikan. Menurut Undang-Undang RI No. 20 Tahun 2003 tentang sistem pendidikan nasional, tujuan dari pendidikan yaitu mendidik peserta didik agar mampu mengembangkan potensi diri untuk menjadi manusia yang beriman dan bertaqwa, pribadi yang baik, memiliki akhlak yang mulia, memiliki ilmu yang bermanfaat dan menjadi masyarakat yang berguna bagi nusa, bangsa dan agama (Undang-Undang Republik Indonesia No 20 Tentang Sistem Pendidikan Nasional, 2003).

\begin{abstract}
Peningkatan kualitas pendidikan dilakukan melalui perubahan dan perkembangan di abad ke-21, salah satunya yaitu perubahan kurikulum. Saat ini kurikulum nasional di Indonesia yaitu kurikulum 2013. Tantangan di bidang pendidikan pada abad ke21 yaitu menyiapkan generasi penerus bangsa yang dapat memecahkan suatu masalah, dapat membuat keputusan dengan bijak, berpikir kreatif, dapat menyampaikan ide-ide secara efektif dan dapat bekerja secara individu maupun kelompok (Simanjuntak et al., 2019). Menghadapi tantangan tersebut, salah satu keterampilan yang dapat dilatihkan kepada peserta didik yaitu keterampilan berpikir kreatif (Creativity), sesuai dengan keterampilan abad 21 yang dibutuhkan oleh peserta didik yaitu keterampilan 4C (Critical Thinking, Creativity, Collaboration, Communication) (Center, 2010).
\end{abstract}


Leen et al., (2014) menyatakan keterampilan berpikir kreatif (Creativity) merupakan kemapuan menemukan ide-ide baru yang bersifat orisinil dan unik dalam pemecahan suatu masalah. Sejalan dengan Arnyana (2019) yang mengemukakan berpikir kreatif melibatkan imajinasi, intuisi, bakat serta kemampuan berpikir secara keseluruhan. Dalam dunia pendidikan keterampilan berpikir kreatif peserta didik berada pada kategori rendah(L. T. Putri et al., 2015). Hal tersebut dikarenakan kurangnya dalam penggunaan model pembelajaran yang variatif yang dapat melatih peserta didik untuk lebih aktif dan kreatif (Khanifah \& Saefan, 2016).

Berdasarkan hasil wawancara yang telah dilakukan Sari et al. (2015) di SMK Cordova selama ini guru cenderung menggunakan model pembelajaran yang bersifat pasif, ceramah dan hanya menerapkan rumus matematis atau perhitungan ketika menyelesaikan permasalahan fisika. Hal tersebut menunjukkan bahwa pembelajaran lebih berfokus pada guru (Teacher Centered), sedangkan pembelajaran yang diharapkan di abad 21 yaitu lebih berfokus pada peserta didik (Student Centered) dimana peserta didik lebih aktif dalam menyelesiakan suatu permasalahan (Khoiri et al., 2016). Dalam mencapai pembelajaran yang diharapkan diperlukan suatu model pembelajaran dan metode yang sesuai, salah satu model pembelajaran yang dapat mengembangkan keterampilan berpikir kreatif serta melibatkan peserta didik untuk lebih aktif yaitu Project Based Learning.

Project Based Learning merupakan model pembelajaran yang membantu peserta didik untuk melakukan eksplorasi, penilaian, interpretasi, sintesis dan mengumpulkan informasi dari berbagai sumber untuk menghasilkan produk yang kreatif. Pembelajaran ini menggunakan pendekatan masalah di kehidupan nyata sebagai bahan untuk belajar tentang kreativitas dan pemecahan masalah (Dwikoranto et al., 2018). Menurut Ridwan dalam penelitian Safitri (2019) mengemukakan model Project Based Learning merupakan pembelajaran yang melibatkan peserta didik dalam merancang, membuat dan menyajikan produk untuk menyelesaikan suatu masalah. Dalam model pembelajaran ini guru berperan sebagai pembimbing dan fasilitator belajar, sehinggga dalam memecahkan permasalahan peserta didik lebih banyak melakukan kegiatan secara mandiri maupum kelompok dengan bimbingan guru. Menurut Sjahrir \& Jatmiko (2015) agar proyek yang dihasilkan maksimal, proyek disesuaikan dengan kemampuan peserta didik.
Fisika merupakan salah satu ilmu yang mempelajari tentang gejala alam serta proses terjadinya gejala alam tersebut. Selain itu fisika juga mempelajari tentang benda-benda yang ada di alam beserta interaksinya. Melalui observasi Sjahrir \& Jatmiko (2015) di SMA Negeri 8 Surabaya terdapat banyak peserta didik yang menganggap fisika merupakan pelajaran yang menghafalkan banyak rumus sehingga dianggap menakutkan.

Berdasarkan uraian diatas, maka dilakukan penelitian dengan tujuan untuk mendeskripsikan pengaruh model Project Based Learning terhadap keterampilan berpikir kreatif peserta didik pada pembelajaran fisika.

\section{METODE PENELITIAN}

Penelitian ini menggunakan jenis penelitian library research. Teknik analisis data pada penelitian dilakukan dengan analisis kualitatif deskriptif dengan menguraikan data, menganalisis dan membahas data, serta mengkaji kesimpulan dari data yang diperoleh. Dalam penelitian ini sumber data berupa data sekunder yang diperoleh dari berbagai sumber jurnal ilmiah nasional, internasional dan prosiding yang terkait dengan pengaruh Project Based Learning terhadap keterampilan berpikir kreatif pada mata pelajaran fisika. Teknik pengumpulan data sekunder didapatkan dari memilih artikel penelitian berdasarkan terbitan dari tahun 2015 hingga 2020, mengidentifikasi data dari artikel untuk dianalisis dan dibahas, dan menyimpulkan data hasil analisis.

\section{HASIL DAN PEMBAHASAN}

Berdasarkan modul Widiarso, E (2016:184) tahap-tahap pelaksanaan model Project Based Learning ada enam tahap yang ditunjukkan pada Gambar 1 berikut.

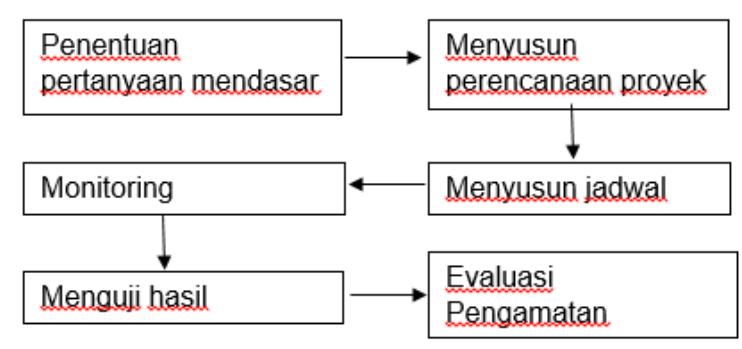

Gambar 1. Langkah-langkah pelaksanaan model Project Based Learning

Keenam tahap dapat mendukung dalam meningkatkan indikator-indikator berpikir kreatif. Indikator berpikir kreatif meliputi fluency (kemampuan berpikir lancar), flexibility (kemampuan berpikir luwes), originality (kemampuan untuk menghasilkan ide orisinil) dan elaboration (kemampuan berpikir terperinci) (Liliawati, 2011). Hubungan antara tahap pelaksanaan Project Based Learning 
dengan indikator berpikir kreatif dapat ditunjukkan pada Tabel 1 berikut.

Tabel 1. Hubungan tahap pelaksanaan Project Based Learning dengan indikator berpikir kreatif

\begin{tabular}{|c|c|}
\hline Tahap & Kegiatan \\
\hline 1 & $\begin{array}{l}\text { Guru menyampaikan topik } \\
\text { pembelajaran yang akan } \\
\text { dipelajari. Kemudian guru } \\
\text { memberikan suatu permasalahan } \\
\text { dan mengajukan pertanyaan } \\
\text { kepada peserta didik mengenai } \\
\text { bagaimana cara memecahkan } \\
\text { masalah yang ada. Peserta didik } \\
\text { memberikan jawaban secara } \\
\text { langsung berdasarkan } \\
\text { kemampuan pemahaman yang } \\
\text { dimiliki. Dengan demikian pada } \\
\text { tahap ini telah melatih indikator } \\
\text { keterampilan berpikir lancar } \\
\text { peserta didik. }\end{array}$ \\
\hline 2 & $\begin{array}{l}\text { Pada tahap ini guru membagi } \\
\text { peserta didik dalam kelompok } \\
\text { untuk mendiskusikan rencana } \\
\text { proses pembuatan proyek yang } \\
\text { digunakan untuk memecahkan } \\
\text { masalah. Hal yang didiskusikan } \\
\text { berupa rancangan proyek, } \\
\text { sumber informasi yang } \\
\text { dibutuhkan, pembagian tugas, } \\
\text { persiapan alat dan bahan, serta } \\
\text { hal-hal yang perlu dilaporkan } \\
\text { setelah proyek selesai. Pada } \\
\text { tahap ini telah melatih kerjasama } \\
\text { kelompok, keterampilan berpikir } \\
\text { kreatif pada indikator berpikir } \\
\text { lancar, berpikir luwes dan berpikir } \\
\text { original karena pada tahap ini } \\
\text { peserta didik memahami suatu } \\
\text { masalah dari berbagai sudut } \\
\text { pandang sehingga mendapatkan } \\
\text { ide-ide yang baru. }\end{array}$ \\
\hline 3 & $\begin{array}{l}\text { Guru bersama peserta didik } \\
\text { membuat kesepakatan mengenai } \\
\text { jadwal pembuatan proyek mulai } \\
\text { dari pembuatan hingga } \\
\text { pengumpulan proyek. Pada } \\
\text { tahap ini dapat melatihkan } \\
\text { keterampilan berpikir lancar } \\
\text { peserta didik, serta melatih } \\
\text { peserta didik untuk mengatur } \\
\text { waktu agar pembuatan proyek } \\
\text { selesai tepat waktu. }\end{array}$ \\
\hline 4 & $\begin{array}{l}\text { Guru memonitor peserta didik } \\
\text { mulai dari } \\
\text { perkembangan dalam proaktifan, } \\
\text { pembuatan proyek, serta } \\
\text { membantu apabila terdapat } \\
\text { kesulitan. Sedangkan peserta } \\
\text { didik melakukan pembuatan }\end{array}$ \\
\hline
\end{tabular}

proyek sesuai dengan rancangan yang telah disepakati, mencatat setiap tahapan, mendiskusikan masalah yang muncul selama proses pembuatan proyek. Dengan demikian pada tahap ini dapat melatih peserta didik untuk berpikir lancar, berpikir luwes, berpikir original dan berpikir elaborasi.

5 Guru menguji proyek yang telah dikerjakan, mengukur ketercapaian standar, mengevaluasi kemajuan masingmasing peserta didik setelah diterapkannya model Project Based Learning.

6 Setiap kelompok melakukan pemaparan proyek sedangkan peserta didik yang lainnya memberikan tanggapan, guru bersama peserta didik melakukan refleksi terhadap kegiatan pembelajaran dan hasil proyek yang dihasilkan.

Dalam setiap model pembelajaran terdapat kelebihan dan kekurangannya. Menurut Ridwan dalam penelitian Safitri (2019) kelebihan dari Project Based Learning yaitu 1) meningkatkan motivasi peserta didik untuk belajar lebih giat, 2) meningkatkan kemampuan peserta didik dalam memecahkan masalah, 3) peserta didik menjadi lebih aktif, 4) mengembangkan kemampuan kerja sama peserta didik dalam satu kelompok, 5) melatihkan kemampuan komunikasi antar peserta didik dalam menyelesaikan masalah melalui diskusi, 6) mengembangkan keterampilan peserta didik dalam mengelola sumber seperti alat dan bahan, 7) menambah ilmu pengetahuan peserta didik dalam mengorganisasi proyek, mengatur waktu, dan mencari solusi untuk menyelesaikan masalah, 8) memberikan kesempatan peserta didik untuk belajar sesuai dengan kondisi di kehidupan nyata, 9) melatih peserta didik untuk mengumpulkan informasi dari berbagai sumber dan menerapkannya dalam menyelesaikan masalah, dan 10) menciptakan suasana belajar yang menyenangkan, sedangkan untuk kekurangan dari Project Based Learning yaitu 1) dalam kerja kelompok terdapat kesulitan untuk melibatkan seluruh peserta didik dalam mengerjakan proyek, 2) biaya yang dibutuhkan banyak, 3) membutuhkan fasilitas serta peralatan yang memadai untuk mengerjakan proyek, dan 4) untuk memecahkan masalah dan menyelesaiakan produk diperlukan banyak waktu hal ini sejalan dengan penelitian 
sebelumnya yang dilakukan oleh Nugraheni (2018) dalam pembuatan proyek terdapat juga peserta didik yang mengalami kendala atau produk gagal, hal tersebut terjadi karena peserta didik belum paham mengenai konsep yang dipelajari. Kemudian peserta didik memahami konsep serta menganalisis kendala dan membuat proyek dengan alat dan bahan yang lebih variatif.

Hasil penelitian yang dilakukan oleh $\mathrm{W}$. P. Sari et al. (2018) pada materi fluida statis menunjukkan bahwa proyek atau alat yang dikerjakan peserta didik berhasil. Peserta didik terlibat secara aktif dalam pembuatan proyek dan mencari informasi dari berbagai sumber maupun berdiskusi dengan guru, dan bertukar ide apabila mengalami kendala sehingga mempermudah dalam pembuatan proyek.

Tabel 2. Analisis pengaruh model Project Based Learning terhadap kemampuan berpikir kreatif peserta didik

\begin{tabular}{|c|c|c|}
\hline No & Penulis & Analisis Artikel \\
\hline 1 & $\begin{array}{l}\text { (Nurfa \& } \\
\text { Nana, 2020) }\end{array}$ & $\begin{array}{l}\text { Sumber Jurnal: } \\
\text { Jurnal Penelitian Pendidikan } \\
\text { Fisika Vol.5 No.2 (2020) } \\
\text { Judul: } \\
\text { Pengaruh Model Project } \\
\text { based Learning Terintegrasi } \\
\text { 21st Century Skills Terhadap } \\
\text { Kemampuan Berpikir Kreatif } \\
\text { Siswa SMA Fisika } \\
\text { Hasil Analisis: } \\
\text { Pembelajaran fisika } \\
\text { menggunakan model Project } \\
\text { Based Learning berpengaruh } \\
\text { terhadap keterampilan } \\
\text { berpikir kreatif peserta didik } \\
\text { karena didukung oleh } \\
\text { perancangan proyek sesuai } \\
\text { dengan permasalahan, } \\
\text { kerjasama tim dan peran } \\
\text { guru dalam pembuatan } \\
\text { proyek, serta ide-ide kreatif } \\
\text { yang ditemukan oleh peserta } \\
\text { didik. }\end{array}$ \\
\hline 2 & $\begin{array}{l}\text { (Shalihah et } \\
\text { al., 2020) }\end{array}$ & $\begin{array}{l}\text { Sumber Jurnal: } \\
\text { Journal of Physics: } \\
\text { Conference Series Vol.1563 } \\
\text { No.1 } \\
\text { Judul: } \\
\text { The analysis of the } \\
\text { application of learning } \\
\text { materials based on project } \\
\text { based leraning to improve } \\
\text { the elementary school } \\
\text { students' creative thinking } \\
\text { skills in slovingcontextual } \\
\text { division problems } \\
\text { Hasil Analisis: } \\
\text { Penerapan Project Based }\end{array}$ \\
\hline
\end{tabular}

Learning efektif dalam meningkatkan keterampilan berpikir kreatif dengan melibatkan peserta didik dalam pemecahan masalah seperti menganalisis pertanyaan, menemukan teknik termudah dalam menjawab pertanyaan, menyelesaikan tugas tepat waktu, dan menguraikan jawabannya dengan detail.

\begin{tabular}{ll}
\hline (Amalia et al., \\
2019)
\end{tabular}

Sumber Jurnal:

Prosiding Seminar Nasional Lontar Physics Forum, 106112 (2019)

Judul:

Keefektifan Model Project Based Learning (PjBL) untuk Meningkatkan Kemampuan Berpikir Kreatif Siswa Kelas $X$ SMA Kesatrian 2 Semarang pada Materi Usaha dan Energi

Hasil Analisis:

Project Based Learning efektif dalam meningkatkan kemampuan berpikir kreatif karena peserta didik dengan lancar dapat menciptakan ide-ide yang kreatif dan orisinil dalam mengembangkan proyek.

\begin{tabular}{ll}
\hline 4 (Arnyana \\
2019)
\end{tabular}
Sumber Jurnal:

Prosiding: Konferensi Nasional Matematika dan IPA Universitas PGRI Banyuwangi (2019)

Judul:

Pembelajaran untuk Meningkatkan Kompetensi 4C (Communication, Collaboration, Critical Thinking, dan Creative Thinking) untuk Menyongsong Era Abad 21

Hasil Analisis:

Kemampuan berpikir kreatif merupakan kemampuan menciptakan ide baru yang berbeda dengan ide yang sudah ada. Kemampuan ini dapat dilatihkan dengan strategi pembelajaran yang diawali dengan disediakannya masalah. Salah satu strategi tersebut yaitu Project Based Learning.

5 (Milla et al., Sumber Jurnal: 


\begin{tabular}{|c|c|c|}
\hline & 2019) & $\begin{array}{l}\text { Unnes Science Education } \\
\text { Journal Vol.8 No.1 (2019) } \\
\text { Judul: } \\
\text { The Effectiveness pf Project- } \\
\text { Based Learning for Biology } \\
\text { Class in Developing the } \\
\text { Science Processing Skills } \\
\text { and Creativity of High School } \\
\text { Students } \\
\text { Hasil Analisis: } \\
\text { Proyek yang telah dibuat } \\
\text { oleh peserta didik dinilai } \\
\text { berdasarkan indikator } \\
\text { kreativitas yang terdapat } \\
\text { dalam instrument penilaian } \\
\text { untuk mengetahui tingkat } \\
\text { kreativitas peserta didik. } \\
\text { Pada penelitian in } \\
\text { rekapitulasi kreativitas } \\
\text { peserta didik menunjukkan } \\
\text { skor 69, dimana skor } \\
\text { tersebut berada dalam } \\
\text { kriteria efektif. }\end{array}$ \\
\hline 6 & $\begin{array}{l}\text { (S. U. Putri et } \\
\text { al., 2019) }\end{array}$ & $\begin{array}{l}\text { Sumber Jurnal: } \\
\text { Journal of Physics: } \\
\text { Conference Series Vol.1157 } \\
\text { No.2 } \\
\text { Judul: } \\
\text { Improving creative thinking } \\
\text { skill through project-based- } \\
\text { learning in science for } \\
\text { primary school } \\
\text { Hasil Analisis: } \\
\text { Project Based learning dapat } \\
\text { memfasilitasi peserta didik } \\
\text { dalam meningkatkan } \\
\text { keterampilan berpikir kreatif } \\
\text { melalui kegiatan menyelidiki } \\
\text { masalah, mengumpulkan } \\
\text { informasi dari berbagai } \\
\text { sumber, menemukan ide, } \\
\text { merancang proyek, serta } \\
\text { mengembangkan proyek. }\end{array}$ \\
\hline 7 & $\begin{array}{l}\text { (Simanjuntak } \\
\text { et al., 2019) }\end{array}$ & $\begin{array}{l}\text { Sumber Jurnal : } \\
\text { Jurnal Inovasi Pembelajaran } \\
\text { Vol. } 7 \text { No. } 3 \text { (2019) } \\
\text { Judul: } \\
\text { Desain Pembelajaran } \\
\text { Berbasis Proyek Terhadap } \\
\text { 4C } \\
\text { Hasil Analisis: } \\
\text { Project Based Learning } \\
\text { menuntut peserta didik } \\
\text { memecahkan masalah } \\
\text { dengan berbagai strategi } \\
\text { melalui pembuatan proyek, } \\
\text { serta menemukan ide-ide } \\
\text { baru yang kreatif dan inovatif } \\
\text { sehingga dapat melatihkan } \\
\text { kemampuan berpikir kreatif }\end{array}$ \\
\hline
\end{tabular}

peserta didik.

\begin{tabular}{lll}
\hline & & peserta didik. \\
\hline $8 \quad$ (Umamah \& & Sumber Jurnal: \\
& Andi, 2019) & Jurnal Pendidikan Fisika dan \\
& Keilmuan Vol.5 No. 1 (2019) \\
& Judul: \\
& Pengaruh Model Project \\
& Based Learning Terhadap \\
& Keterampilan Berpikir Kreatif \\
& dalm Pembelajaran Fisika \\
& Terapan \\
& Hasil Analisis: \\
& Terdapat pengaruh yang \\
& signifikan penggunaan \\
& model Project Based \\
& Learning terhadap
\end{tabular}
keterampilan berpikir kreatif, urutan presentase indikator berpikir kreatif dari skor yang tertinggi yaitu berpikir lancar, berpikir elaborasi, berpikir luwes dan berpikir orisinil.

9 (Viana et al., Sumber Jurnal: 2019) Journal of Physics: Conference Series Vol.1233 No.1 Judul: The Influence of Project Based Learning based on Process Skills Approach to Student's Creative Thinking Skill Hasil Analisis:

Peserta didik menyelesaikan masalah dari berbagai sudut pandang sehingga memiliki keleluasaan berpikir untuk menemukan ide baru yang unik dan kreatif, serta melatihkan untuk berpikir secara lancar dan terperinci.

10 (Anitha et al., Judul: 2018) Journal of Engineering Education Transformations Vol.32 No.2 (2018)

Judul:

Assessing and Enhancing Creativity in a Laboratory Course with Project Based Learning Hasil Analisis:

Project Based Learning memberikan ruang kepada peserta didik untuk lebih fokus terhadap pertanyaan, mendesain proyek, setiap peserta didik dapat mengusulkan ide-ide yang dimiliki serta membuat proyek sehingga proyek yang dihasilkan maksimal. 
Volume 7, Nomor 1, Mei 2021.

p-ISSN : 2460-9587

e-ISSN : 2614-7017

\begin{tabular}{lll}
\hline 11 (Fajrina et al., & Sumber Jurnal: \\
& Jurnal Pendidikan: Teori, \\
& Penelitian, & dan \\
& Pengembangan Vol.3 No.3 \\
& Judul: \\
& Peran Model Project Based \\
& Learning dalam Kemampuan \\
& Berpikir Kreatif Kelas XI IPA \\
& melalui Materi Fluida Statis \\
& Hasil Analisis:
\end{tabular}

Kemampuan berpikir kreatif pada kelas dengan model Project Based Learning lebih baik dibandingkan kelas dengan model pembelajaran konvensional hal tersebut dibuktikan dari perbedaan nilai rata-rata di kedua kelas, sehingga Project Based Learning dapat mempengaruhi kemampuan berpikir kreatif peserta didik.

\begin{tabular}{ll}
\hline 12 & (Nugraheni, \\
& 2018)
\end{tabular}

Sumber Jurnal:

Jurnal Penelitian

Pembelajaran Fisika Vol. 9

No. 2 (2018)

Judul:

Pembelajaran Berbasis

Proyek (Project Based

Learning) Materi Kalor dan

Perpindahannya untuk

Meningkatkan Kreativitas

Siswa

Hasil Analisis:

Peserta didik dapat menerapkan ide kreatif atau konsep yang dimiliki kedalam proyek yang dirancang, sehingga melalui Project Based Learning guru dapat mengetahui tingkat kreativitas peserta didik.

\begin{tabular}{ll}
\hline (Raniah et al., & Sumber Jurnal: \\
& Prosiding Seminar Nasional \\
& Fisika (SINAFI) (2018) \\
& Judul: \\
& Profil Keterampilan Abad 21 \\
& pada Pembelajaran Project \\
& Based Learning (PjBL) \\
& Materi Gelombang Bunyi \\
& Hasil Analisis: \\
& Keterampilan berpikir kreatif \\
& peserta didik sebagian besar \\
& berada pada kategori \\
& dibawah standar hal tersebut \\
& dikarenakan $\quad$ dalam \\
& menyelesaikan masalah \\
& peserta didik terbiasa \\
& menggunakan langkah- \\
& langkah yang telah disajikan, \\
\hline
\end{tabular}

peserta didik hanya

mengikutinya. Selain itu

dalam menyajikan atau mempresentasikan proyek peserta didik hanya menggunakan satu media presentasi membuat audiens merasa kurang tertarik.

\begin{tabular}{ll}
\hline 14 & (W. P. Sari et \\
& al., 2018)
\end{tabular}

Sumber Jurnal:

Jurnal Pendidikan: Teori,

Penelitian, dan

Pengembangan Vol.3 No.6

(2018)

Judul:

Keterampilan Berpikir Kreatif

Siswa SMA dalam

Pembelajaran Project Based

Learning (PjBL) pada Materi

Fluida Statis

Hasil Analisis:

Proses pembelajaran

peserta didik menjadi lebih

bermakna dengan

pembuatan simulasi proyek

karena peserta didik dapat

memahami materi dan

konsep secara mandiri

melalui berbagai sumber

informasi untuk

menyelesaikan

permasalahan.

15 (Diawati et al., Sumber Jurnal:

2017) AIP Conference Proceedings

Vol.1848 No.1

Judul:

Students' Construction of a

Simple Steam Distillation

Apparatusand Development

of Creative Thinking Skills: A

Project-Based Learning

Hasil Analisis:

Dalam Project Based

Learning peserta didik

diarahkan untuk

merumuskan masalah,

mengusulkan ide-ide,

mendesain proyek, membuat

proyek, menguji dan

melaporkan proyek sehingga

dapat mengembangkan

keterampilan berpikir kreatif

serta mempermudah peserta

didik untuk memahami

konsep dan prinsip kerja perangkat.

\begin{tabular}{llll}
\hline 16 & (Chasanah et & Sumber Jurnal: & \\
& al., 2016) & Jurnal & Penelitian \\
& & Pembelajaran Fisika Vol.7 \\
& No.1 (2016) & \\
& & Judul: \\
&
\end{tabular}


Volume 7, Nomor 1, Mei 2021.

p-ISSN : 2460-9587

e-ISSN : 2614-7017

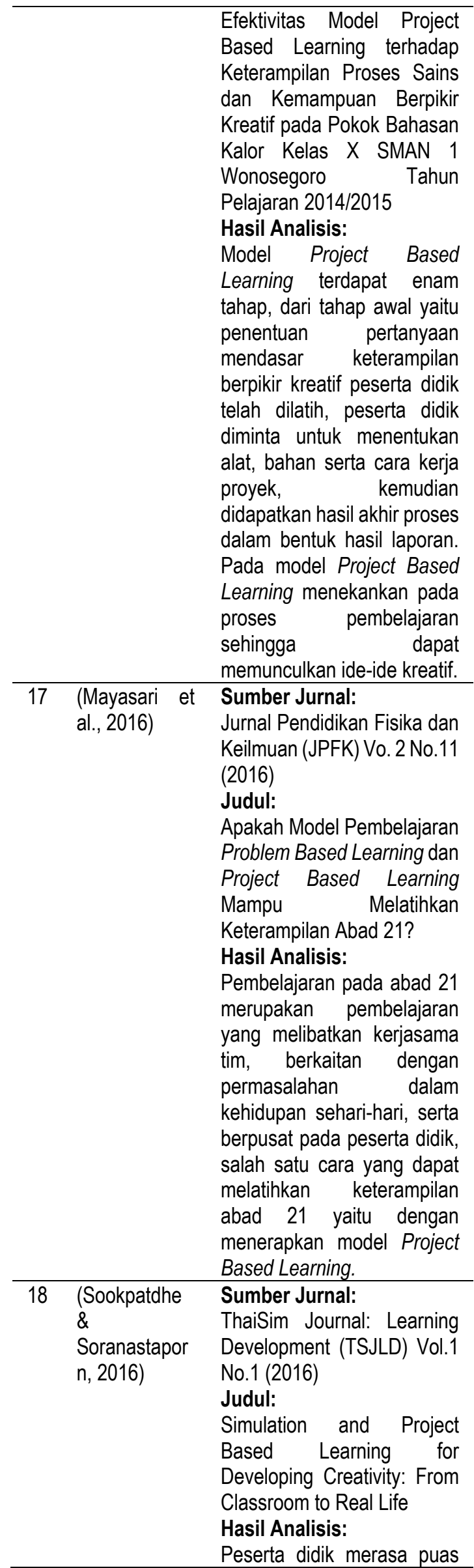

\begin{tabular}{|c|c|}
\hline & $\begin{array}{l}\text { dengan pembelajaran } \\
\text { berbasis proyek karena } \\
\text { selain memperoleh } \\
\text { penjelasan materi dari guru } \\
\text { peserta didik juga } \\
\text { memperoleh pengetahuan } \\
\text { dari teman sebaya dengan } \\
\text { cara bertukar jawaban, ide } \\
\text { atau gagasan, serta dapat } \\
\text { mengasah keterampilan } \\
\text { peserta didik untuk } \\
\text { menyelesaikan } \\
\text { permasalahan dengan ide- } \\
\text { ide kreatif yang telah } \\
\text { didapatkan. Sehingga } \\
\text { peserta didik dapat membuat } \\
\text { produk baru. }\end{array}$ \\
\hline $\begin{array}{l}19 \text { (D. N. Sari et } \\
\text { al., 2015) }\end{array}$ & $\begin{array}{l}\text { Sumber Jurnal: } \\
\text { Prosiding Seminar Nasional } \\
\text { Fisika (E-Journal) Vol. } 4 \\
\text { (2015) } \\
\text { Judul: } \\
\text { Pengaruh Pembelajaran } \\
\text { Berbasis Proyek Terhadap } \\
\text { Kreativitas Sisiwa Melalui } \\
\text { Elektroskop Sederhana } \\
\text { Hasil Analisis: } \\
\text { Project Based Learning } \\
\text { melatih peserta didik untuk } \\
\text { merancang proyek sesuai } \\
\text { dengan kemampuan individu } \\
\text { yang dikerjakan secara } \\
\text { berkelompok serta dapat } \\
\text { melatih peserta didik untuk } \\
\text { lebih aktif dan komunikatif. }\end{array}$ \\
\hline $\begin{array}{ll}20 & \text { (L. T. Putri et } \\
& \text { al., 2015) }\end{array}$ & 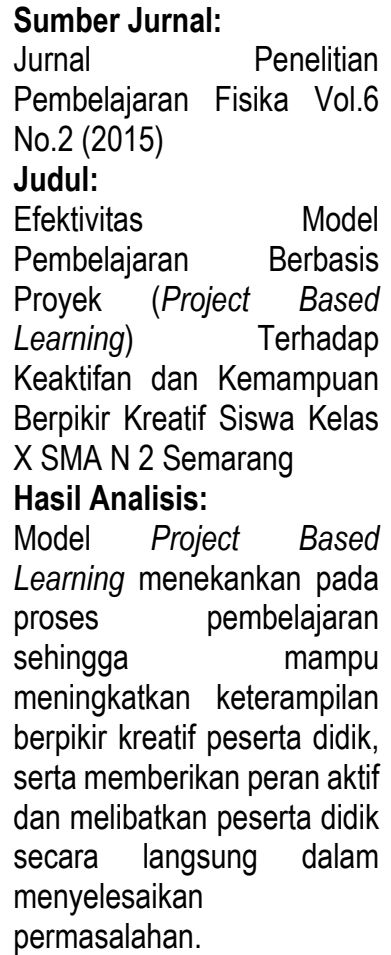 \\
\hline
\end{tabular}


Hasil penelitian lainnya yang telah dilakukan oleh Chasanah et al. (2016) menunjukkan bahwa kemampuan berpikir kreatif dengan menggunakan model Project Based Learning lebih efektif dibandingkan dengan model pembelajaran konvensional dapat ditunjukkan pada Tabel 3.

Tabel 3. Hasil posttest kemampuan berpikir kreaif peserta didik

\begin{tabular}{ccc}
\hline \multirow{2}{*}{ Statistik } & \multicolumn{2}{c}{ Kelas } \\
\cline { 2 - 3 } & Eksperimen & Kontrol \\
\hline Jumlah Siswa & 30 & 30 \\
\hline Rata-rata Nilai & 76 & 63 \\
\hline Nilai Minimum & 61 & 32 \\
\hline Nilai Maksimum & 93 & 82 \\
\hline Standar Deviasi & 8,56 & 13,68 \\
\hline
\end{tabular}

Berdasarkan tabel hasil posttest terdapat kelas eksperimen yang menggunakan model Project Based Learning dan kelas kontrol yang menggunakan model pembelajaran konvensional. Tabel diatas menunjukkan bahwa model Project Based Learning berpengaruh terhadap kemampuan berpikir kreatif dibuktikan dengan hasil uji t dengan nilai $t_{\text {hitung }}=29,46$ dan $t_{\text {tabel }}=1,672$.

Ditinjau dari penelitian sebelumnya yang telah dilakukan oleh Amalia et al. (2019) dengan menggunakan model Project Based Learning peserta didik menjadi lebih kreatif dalam menemukan ide-ide baru yang bersifat orisinil sesuai materi atau konsep yang digunakan dalam mengembangkan proyek. Serta melatihkan peserta untuk berpikir secara lancar, luwes dalam menyelesaikan masalah dan dapat merincikan atau menjelaskan proyek beserta konsep yang telah dikerjakan. Hal ini mengakibatkan adanya perbedaan keterampilan berpikir kreatif peserta didik sebelum dan sesudah diterapkan Project Based Learning. Jadi dengan menerapkan model Project Based Learning dapat meningkatkan keterampilan berpikir kreatif peserta didik pada pembelajaran fisika.

\section{SIMPULAN DAN SARAN}

Dalam menghadapi rendahnya keterampilan berpikir kreatif, serta menyelesaikan masalah yang menganggap bahwa fisika merupakan pelajaran yang menakutkan dapat dilakukan dengan menerapkan Project Based Learning. Berdasarkan hasil analisis dapat disimpulkan bahwa Project Based Learning dapat meningkatkan keterampilan berpikir kreatif peserta didik pada pembelajaran fisika.

\section{DAFTAR RUJUKAN}

Amalia, L. N., Saefan, J., \& Siswanto, J. (2019). Keefektifan Model Project Based Learning
(Pjbl) untuk Meningkatkan Kemampuan Berfikir Kreatif Siswa Kelas X SMA Kesatrian 2 Semarang pada Materi Usaha dan Energi. Prosiding Seminar Nasional Lontar Physics Forum, 106-112.

Anitha, D., Jeyamala, C., \& Kavitha, D. (2018). Assessing and enhancing creativity in a laboratory course with project based learning. Journal of Engineering Education Transformations, 32(2), 67-74. https://doi.org/10.16920/jeet/2018/v32i2/1 39505

Arnyana, I. B. P. (2019). PEMBELAJARAN UNTUK MENINGKATKAN KOMPETENSI 4C(COMMUNICATION, COLLABORATION, CRITICAL THINKING DAN CREATIVE THINKING) UNTUK MENYONGSONG ERA ABAD 21. In Prosiding: Konferensi Nasional Matematika dan IPA Universitas PGRI Banyuwangi.

Center, P. P. R. (2010). 21st Century Skills for Students and Teachers. Honolulu: Kamehameha Schools. Research \& Evaluation Division.

Chasanah, A. R. U., Khoiri, N., \& Nuroso, H. (2016). Efektivitas Model Project Based Learning terhadap Keterampilan Proses Sains dan Kemampuan Berpikir Kreatif Siswa pada Pokok Bahasan Kalor Kelas X SMAN 1 Wonosegoro Tahun Pelajaran 2014/2015. Jurnal Penelitian Pembelajaran Fisika, 7(1), 19-24. https://doi.org/10.26877/jp2f.v7i1.1149

Diawati, C., Liliasari, Setiabudi, A., \& Buchari. (2017). Students' construction of a simple steam distillation apparatus and development of creative thinking skills: A project-based learning. AIP Conference Proceedings, 1848(1), 30002.

Dwikoranto, Setiani, R., Madlazim, \& Erman. (2018). Validity of Project Based Laboratory Learning: An Innovative Physics Laboratory Learning to prepare Sciences Process Skills and Creativity of Physics Teacher Candidate. International Conference on Science and Technology (ICST 2018), 912-917.

Fajrina, R. N. A. A., Handayanto, S. K., \& Hidayat, A. (2018). Peran Model Project Based Learning dalam Kemampuan Berpikir Kreatif Kelas XI IPA melalui Materi Fluida Statis. Jurnal Pendidikan: Teori, Penelitian, dan Pengembangan, $3(3)$, 291-295. http://journal.um.ac.id/index.php/jptpp/arti cle/view/10625/5202

Khanifah, K., \& Saefan, J. (2016). Pengaruh Model Project Based Learning melalui Metode Praktikum terhadap Kemampuan 
Berpikir Kreatif pada Materi Getaran Harmonis Siswa Kelas XI MIA SMA Negeri 1 Comal. Jurnal Penelitian Pembelajaran Fisika, 7(1), 49-55. https://doi.org/10.26877/jp2f.v7i1.1141

Khoiri, N., Marinia, A., \& Kurniawan, W. (2016). Keefektifan Model Pembelajaran PjBL (Project Based Learning) terhadap Kemampuan Kreativitas dan Hasil Belajar Siswa Kelas XI. Jurnal Penelitian Pembelajaran Fisika, 7, 142-146. https://doi.org/10.26877/jp2f.v7i2.1309

Leen, C. C., Hong, H., Kwan, F. F. H., \& Ying, T. W. (2014). Creative and critical thinking in Singapore schools. Singapore: Nanyang Technological University.

Liliawati, M. W. (2011). Pembekalan keterampilan berpikir kreatif siswa sma melalui pembelajaran fisika berbasis masalah. Jurnal Pengajaran MIPA, 16(2), 93-98.

Mayasari, T., Kadarohman, A., Rusdiana, D., \& Kaniawati, I. (2016). Apakah Model Pembelajaran Problem Based Learning Dan Project Based Learning Mampu Melatihkan Keterampilan Abad 21? Jurnal Pendidikan Fisika dan Keilmuan (JPFK), 2(1), $\quad$ 48-55. https://doi.org/10.25273/jpfk.v2i1.24

Milla, D., Jufri, A. W., \& Soepriyanto, H. (2019). The effectiveness pf project-based learning for biology class in developing the science processing skills and creativity of high school students. Unnes Science Education Journal, 8(1), 25-30.

Nugraheni, D. (2018). Pembelajaran Berbasis Proyek (Project Based Learning) Materi Kalor dan Perpindahannya untuk Meningkatkan Kreativitas Siswa. Jurnal Penelitian Pembelajaran Fisika, 9(2), 7379.

https://doi.org/10.26877/jp2f.v9i2.2798

Nurfa, N. N., \& Nana, N. (2020). Pengaruh Model Project Based Learning Terintegrasi 21st Century Skills Terhadap Kemampuan Berpikir Kreatif Siswa SMA Fisika. Jurnal Penelitian Pendidikan Fisika, $5(2)$, 109-115. https://doi.org/10.36709/jipfi.v5i2.11522

Putri, L. T., Nuroso, H., \& Khoiri, N. (2015). Efektivitas Model Pembelajaran Berbasis Proyek (Project Based Learning) Terhadap Keaktifan Dan Kemampuan Berpikir Kreatif Siswa Kelas X Sma N 2 Semarang. Jurnal Penelitian Pembelajaran Fisika, 6(2), 38-43. https://doi.org/10.26877/jp2f.v6i2.2590

Putri, S. U., Sumiati, T., \& Larasati, I. (2019). Improving creative thinking skill through project-based-learning in science for primary school. Journal of Physics: Conference Series, 1157(2). https://doi.org/10.1088/17426596/1157/2/022052

Raniah, D., Efendi, R., \& Liliawati, W. (2018). Profil Keterampilan Abad 21 pada Pembelajaran Project Based Learning (PjBL) Materi Gelombang Bunyi. Prosiding Seminar Nasional Fisika (SINAFI), 2018.

Safitri, M. (2019). PENGARUH MODEL PEMBELAJARAN PROJECT BASED LEARNING DAN PROBLEM BASED LEARNING UNTUK MENINGKATKAN BERPIKIR KREATIF MATEMATIS SISWA. UIN Raden Intan Lampung.

Sari, D. N., Sutikno, \& Masturi. (2015). Pengaruh Pembelajaran Berbasis Proyek terhadap Kreativitas Siswa melalui Elektroskop Sederhana. Prosiding Seminar Nasional Fisika (E-Journal) SNF2015, 4, 19-24.

Sari, W. P., Hidayat, A., \& Kusairi, S. (2018). Keterampilan Berpikir Kreatif Siswa SMA dalam Pembelajaran Project Based Learning ( Pjbl ) pada Materi Fluida Statis. Jurnal Pendidikan: Teori, Penelitian, dan Pengembangan, 3(6), 751-757.

Shalihah, N. H., Dafik, \& Prastiti, T. D. (2020). The analysis of the application of learning materials based on project-based learning to improve the elementary school students' creative thinking skills in solving contextual division problems. Journal of Physics: Conference Series, 1563(1). https://doi.org/10.1088/17426596/1563/1/012044

Simanjuntak, M. P., Bukit, N., Sagala, Y. D. A., Khairani Putri, R., Utami, laksmitha zaskya, \& Motlan. (2019). Desain Pembelajaran Berbasis Proyek Terhadap 4C. Jurnal Inovasi Pembelajaran Fisika (INPAFI), 7(3), 38-46. https://doi.org/https://doi.org/10.24114/inp afi.v7i3.14570

Sjahrir, A., \& Jatmiko, B. (2015). Penerapan Pembelajaran dengan Model Project Based Learning Berbasis Laboratorium Virtual untuk Meningkatkan Hasil Belajar Siswa pada Materi Pemanasan Global. Jurnal Inovasi Pendidikan Fisika, 04(03), 92-96.

Sookpatdhe, T., \& Soranastaporn, S. (2016). Simulation and project based learning for developing creativity: From classroom to real life. ThaiSim Journal: Learning Development (TSJLD), 1(1), 85-105. http://www.thaisim.org/sgld/

Umamah, C., \& Andi, H. J. (2019). Pengaruh Model Project Based Learning Terhadap Keterampilan Berpikir Kreatif Dalam 
Pembelajaran Fisika Terapan. Jurnal Pendidikan Fisika dan Keilmuan (JPFK), 5(1),

$7-14$.

https://doi.org/10.26877/jp2f.v10i1.3507

Undang-Undang Republik Indonesia No 20 Tentang Sistem Pendidikan Nasional, Jakarta: Direktorat Pendidikan Menengah Umum (2003).

Viana, R. V., Jumadi, Wilujeng, I., \& Kuswanto, $H$. (2019). The Influence of Project Based Learning based on Process Skills Approach to Student's Creative Thinking Skill. Journal of Physics: Conference Series, 1233(1). https://doi.org/10.1088/1742$6596 / 1233 / 1 / 012033$ 